\title{
A Comparative Morphological Study on Amaranthus spinosus L., Celosia argentea L. and Gomphrena celosioides Mart (AMARANTHACEAE)
}

\author{
N. F. Okeke ${ }^{1, *}$, C. V. Ilodibia ${ }^{1}$, B. E. Okoli ${ }^{2}$ \\ ${ }^{1}$ Department of Botany, Nnamdi Azikiwe University, Nigeria \\ ${ }^{2}$ Department of Plant Science and Biotechnology, University of Port Harcourt, Nigeria
}

Received October 12, 2019; Revised December 16, 2019; Accepted December 25, 2019

Copyright $\subseteq 2020$ by authors, all rights reserved. Authors agree that this article remains permanently open access under the terms of the Creative Commons Attribution License 4.0 International License

\begin{abstract}
A comparative morphological study on Amaranthus spinosus, Celosia argentea and Gomphrena celosioides was evaluated and compared to determine their taxonomic morphological characters that delimit them as members of the family Amaranthaceae. This was done by use of hand lens and visual observations of the plants parts. Results showed similarities in their possession of simple leaves, small flowers, inflorescence as spike, being herbaceous with woody base, having pentamerous perianths and stamens, exstipulate and presence of pinkish pigment in any of the plant parts, while they differed in the possession of spines by Amaranthus spinosus and trichomes by Gomphrena celosioides. Information from this study is valuable for taxonomic characterisation and identification of the plant species in the family Amaranthaceae. Their possession of pinkish pigment in any of the parts shows that they can be a source of vitamin A since lycopene responsible for that pinkish character has the same structure as carotene.
\end{abstract}

Keywords Amaranthaceae, Amaranthus spinosus, Celosia argentea, Gomphrena celosioides, Comparative, Morphology, Delimitation

\section{Introduction}

The family Amaranthaceae contains 65 genera and 900 species, mainly in the tropics and subtropics, often occurring as weeds or escapes from cultivation. In West Africa, it is represented by 14 genera and 37 species [1]. The leaves are alternate or opposite, simple, exstipulate and generally entire. The flowers are bisexual, or unisexual, typically very small and frequently prickly due to bristly perianth and bracts. Each flower is subtended by a bract and two bractlets that commonly are scarious or membranous. The leaves of some members of this family are used as vegetable; examples are Amaranthus hybridus, Amaranthus spinosus and Celosia argentea. Some are raised as cereals in tropical Asia e.g A. cruentus, A. frumentacea and $A$. caudatus. Some are grown as ornamentals e.g. Alternanthera, Gomphrena, Aerva and Celosia (cock's comb). Achyranthus aspera plants are used as an antidote for poison of snakes and scorpions [1]. Plants from the Amaranthaceae are used in folk medicine for their nutritional qualities and for the treatment of various disorders such as gastrointestinal and respiratory problems, skin infections as well as some infectious diseases and as an abortifacient [2]. Amaranthus spinosus L., Celosia argentea L. and Gomphrena celosioides Mart. which are among the species commonly found in south eastern Nigeria are the points of interest in this research. Amaranthus spinosus Linn.

Amaranthus spinosus is an erect prickly annual herb up to $60 \mathrm{~cm}$ high and reproducing from seeds. The stem is fleshy, round and hairless, greenish but sometimes reddish and always with rigid, sharp pointed spines about $10 \mathrm{~mm}$ long. The leaves are alternate, ovate to broadly-lanceolate, $6-8 \mathrm{~cm}$ long and $2-4 \mathrm{~cm}$ broad, tapering into slender petioles about $7 \mathrm{~cm}$ long beneath which are the spines. The inflorescence consists of long terminal and short axillary spikes. The flowers are small, greenish and occur in clusters with male flower at the top and the female flowers below. The fruit is a one seeded capsule with shiny, lens-shaped reddish -brown seeds [3]. The seed is used as a poultice for broken bones [4]. The plant is astringent, diaphoretic, diuretic, emollient, febrifuge and galactagogue [5]. It is used internally in the treatment of internal bleeding, diarrhoea and excessive menstruation [4]. It is also used in the treatment of snake bites [4].Applied externally, it is used to treat ulcerated mouths, vaginal discharges, 
nosebleeds and a range of skin problems including wounds, eczema, boils and burns [4].The root is diuretic, emmenagogue, febrifuge and galactagogue.The juice of the root is used in Nepal to treat fevers, urinary troubles, diarrhoea and dysentery [5]. It is also used, often combined with the root juice of Dichrophela integra and Rubus ellipticus, to treat stomach disorders and, on its own, to treat indigestion and vomiting that occur after eating unusual foods [5].

Celosia argentea $L$. is a leafy vegetable crop. It is one of the most versatile herbaceous plants characterized with fast growth. It has erect stem with alternate leaves and few branches. The inflorescence is found at the tip of stems. The larger pink appendages of the central open flower comprise the calyx. The pink rimmed, white crown-like structure bearing anthers is the androecium. The pistil with its green ovary and pink style can be seen in the center of the flower. The bracts and bractlets, smaller than the flowers in this case, are best seen in association with the unopened flower. It is propagated by seed; the seedlings emerge 5-7 days after sowing and flowering 6-7 weeks after sowing [6]. Pollination is by wind and insects especially bees and flies which visit the flowers regularly. Seed maturity starts from the basal part of the inflorescence and gradually moves up to the tip. Seeds get matured in 10-16 weeks after sowing. The flowers and seed are astringent, haemostatic, ophthalmic, parasiticide and poultice [7]. They are used in the treatment of bloody stool, haemorrhoid bleeding, uterine bleeding, leucorrhoea, dysentery and diarrhoea [7]. As a parasiticide it is very effective against Trichomonas, a 20\% extract can cause the Trichomonas to disappear in 15 minutes [7]. The seed is hypotensive and ophthalmic. It also has an antibacterial action, inhibiting the growth of Pseudomonas [7]. It is used in the treatment of diarrhoea, bloodshot eyes, blurring of vision, cataracts and hypertension, but should not be used by people with glaucoma because it dilates the pupils. The seeds are widely used in India for the treatment of diabetes mellitus [8]. The roots are used in the treatment of colic, gonorrhoea and eczema [7]. It is used traditionally for the treatment of jaundice, gonorrhea, wounds and fever. The leaves are used for the treatment of inflammations, fever and itching [7].

Gomphrena celosioides is a hairy, decumbent annual or perennial about $20 \mathrm{~cm}$ high with woody tap root and reproducing from seeds. The stem is slender, weak, contracted at the nodes, the upper portion beset with white pilose hairs. The leaves are opposite, oblong or lanceolate, $3-5 \mathrm{~cm}$ long and $1.0-1.15 \mathrm{~cm}$ broad, without petioles but with white moderately stiff hairs on the leaf surface. The inflorescence consists of shortly cylindrical spikes about $2 \mathrm{~cm}$ long and $1 \mathrm{~cm}$ across, and they occur at stem tips. The flowers are yellow and inconspicuous and are subtended by white, ovate bracts that are somewhat toothed. The fruits are indehiscent and one-seeded and the seeds are flat [3]. G. celosioides is prevalently used among the rural people of West Africa to treat a wide variety of ailments. It is used in ethno medical practice in Nigeria for treatment of various skin diseases, worm infections and infectious diseases [9]. In South America, the plant is used as an abortifacient [10].

A system of classification of biological organisms which best reflects the totality of their similarities and differences is termed taxonomy, [1]. To classify plants, taxonomists make use of morphology, phylogeny, physiology, phytochemistry, anatomy, cytology, palynology as taxonomic lines of evidence to determine their similarities and differences in order to group them into various taxa [11]. According to Radford [12], the morphological data of plants are easily observable and obtainable, and are "thus used most frequently in taxonomic studies". The evidence from external morphology provides the "basic Language for plant characterization, identification, classification and relationships" [12]. Angiosperms are identified by morphological characters. Natural groups are defined mainly with the help of floral characters [13]. The basic similarity in the morphology of flowers, fruits and seeds within different species, genera, families and orders provides a sound base in characterizing taxonomic groups. Morphology provides majority of the characters used in the construction of systems of taxonomy. Therefore, morphology is closely related to taxonomy and would continue to reign over it for many more years to come [13]. Determination of differences and similarities with regards to morphology of the three species based on the outcome of the study were the objectives of this research.

\section{Materials and Methods}

\subsection{Procurement and Identification of Plant Materials}

The plant species: Amaranthus spinosus, Celosia argentea and Gomphrena celosioides were collected between April-May 2016 within the premises of Nnamdi Azikiwe University Awka ( $\left.6^{\circ} 12 \mathrm{~N}^{\prime}, 7^{\circ} 04 \mathrm{E}^{\prime}\right)$ Anambra State. The samples were authenticated and given voucher number by a taxonomist in the Department of Botany, Nnamdi Azikiwe University, Awka.

\subsection{Morphological Studies}

Observations on vegetative characteristics were studied using samples collected from mature plant. For the leaves, the third and fourth fully opened leaves from the stem tip were used. A meter rule was used to measure the petiole length, leaf length and leaf base. The plant height and stem girth was measured using a tape rule, while the leaf texture, leaf shape, leaf margin, stem colour, leaf arrangement, leaf type, and leaf venation were studied by keen observation (This is as outlined by [14]. 


\section{Results}

Results of the study are shown in Table 1 and Figures 1-35

\subsection{Plants Habitat}

Figures (1-3) shows Amaranthus spinosus, Celosia argentea and Gomphrena celosioides in their natural habitat. A. spinosus and G. celosioides are mostly seen as weed while $C$. argentea is mostly cultivated in farms as vegetable.

\subsection{HaBIT Morphology}

Observations on the morphology of Amaranthus spinosus, Celosia argentea and Gomphrena celosioides plants (figs. 4-6) showed their habit to be erect herbs except for $G$. celosioides which is prostrate. Amaranthus spinosus and $C$. argentea are annuals while $G$. celosioides is perennial.

\subsection{Stem Morphology}

Observations on the morphology of A. spinosus and $C$ argentea stems revealed the following features: the parts of the stem close to the root base are pinkish in colour while others are greenish. The entire stem of Gomphrena celosioides is pinkish-green in colour with hairs and somehow rounded and slender with contracted nodes while those of Celosia argentea and Amaranthus spinosus are rounded and broad without hairs (figs. 7-12).

\subsection{Leaf Morphology}

Observations on the leaf morphology of $\boldsymbol{A}$. spinosus revealed the following features: phyllotaxy is alternate; leaves are simple, margin-entire, venation-reticulate, shape-lanceolate, surface-glabrous, stipule-exstipulate, length- 13-22 cm and width- 4-7 cm tapering into slender petiole of $5-10 \mathrm{~cm}$ long. Celosia argentea: phyllotaxy is alternate, leaves are simple, margin-entire, venation-reticulate, shape-elliptic, surface-glabrous, stipule-exstipulate, length- $15-31 \mathrm{~cm}$ and width- 3-9 cm with short petioles of 2-5 cm long. Gomphrena celosioides: phyllotaxy is opposite, leaves are simple, margin-entire, venation-reticulate, shape-oblanceolate, surface-hairy, stipule-exstipulate, length- 3-5 cm and width- 1-2 cm with very short petiole of $0.3-0.7 \mathrm{~cm}$ long. The leaves of Celosia argentea and Amaranthus spinosus are broad at early stage of development and got reduced as they get older. Also the leaves of Celosia argentea had red patches near the mid rib when young but the red patches disappeared as it gets older (figs. 13 -16).

\subsection{Morphology of Inflorescence and Flower}

Observations on morphology of inflorescence and flower revealed the following features: $\boldsymbol{A}$. spinosus inflorescence is greenish in colour consisting of long terminal and short axillary spikes, flowers are small, greenish and occurred in clusters. The male flowers have five stamens while the female flowers have superior ovary and have three styles. The inflorescence of $\boldsymbol{C}$. Argentea is pinkish and usually terminal. The inflorescence had many bisexual flowers made up of five perianths, five stamens and one style. The inflorescence of $\boldsymbol{G}$. celosioides is whitish and short consisting of many bisexual flowers. Each flower had five perianth, five stamens and a yellowish stigma. The inside is covered with wool-like structure. The inflorescence of $C$. argentea is pinkish when young and white on maturity while that of $A$. spinosus is greenish when young and brown on maturity. That of G. celosioides is white all through its life (figs.17-22).

\subsection{Morphology of Fruit and Seed}

Observations on fruit and seed morphology revealed the following features: The fruit of $\boldsymbol{G}$. celosioides is covered by a wool-like structure and fruit wall is hard which bears the brown coloured seed of $1 \mathrm{~mm}$ in sizes. The fruits of $\boldsymbol{A}$. spinonsus and $C$. argentea are fibrous while the seeds are shiny and black in colour. The seed of C. argentea is $1 \mathrm{~mm}$ in size while that of $A$. spinosus is $0.8 \mathrm{~mm}$ in size (figs. 23-28).

\subsection{Morphology of Pollen Grains}

Observations on pollen grains morphology revealed the following features: The pollen grains of A. Spinosus are spherical with visible exine and intine. C. argentea pollen grains are spherical with distinct exine and intine while that of $G$. celosioides are spherical with stellate exine (figs. 29-31).

\subsection{Root Morphology}

Observations on root morphology revealed the following features: all species have taproot with many lateral roots. The roots of Gomphrena celosioides are whitish while those of Amaranthus spinosus and Celosia argentea milkish in colour. The roots of Celosia argentea have nodule-like structures attached to them (figs. 32-35). 
Table 1. Morphological Features of A. spinosus, C. argentea and G. celosioides

\begin{tabular}{|l|l|l|l|}
\hline Character & A. spinosus & C. argentea & G. celosioides \\
\hline Growth Habit & Erect & Erect & Prostrate \\
\hline Plant Type & Herb & Herb & Herb \\
\hline Stem colour & Green with pink base & Green with pink base & Pinkish green \\
\hline Stem shape & Round & Round & Round and Compressed at the node \\
\hline Plant Height & $65 \mathrm{~cm}-143 \mathrm{~cm}$ & $67 \mathrm{~cm}-145 \mathrm{~cm}$ & $11 \mathrm{~cm}-35 \mathrm{~cm}$ \\
\hline Leaf arrangement & Alternate & Alternate & Opposite \\
\hline Leaf length & $13-22 \mathrm{~cm}$ & $15-31 \mathrm{~cm}$ & $3-5 \mathrm{~cm}$ \\
\hline Leaf width & $4-7 \mathrm{~cm}$ & $3-9 \mathrm{~cm}$ & $1-2 \mathrm{~cm}$ \\
\hline Leaf type & Simple & Simple & Simple \\
\hline Leaf shape & Lanceolate & Elliptic & Oblanceolate \\
\hline Presence of hairs & Glabrous & Glabrous & Pubescent \\
\hline Presence of Spines & Present & Absent & Absent \\
\hline Flower & Unisexual & Bisexual & Bisexual \\
\hline Flower colour & Green & Pink & White \\
\hline Colour of perianth & Green & Pink & White \\
\hline Number of Perianth & Five & Five & Five \\
\hline Number of Stamen & Five & Five & Five \\
\hline Fruit & Fibrous & Fibrous & Hard \\
\hline Seed colour & Black & Black & Brown \\
\hline Size of the seed & $0.8 m m$ & $1 \mathrm{~mm}$ & 1 mm \\
\hline Root Colour & Milk colour & Milk colour & White \\
\hline
\end{tabular}

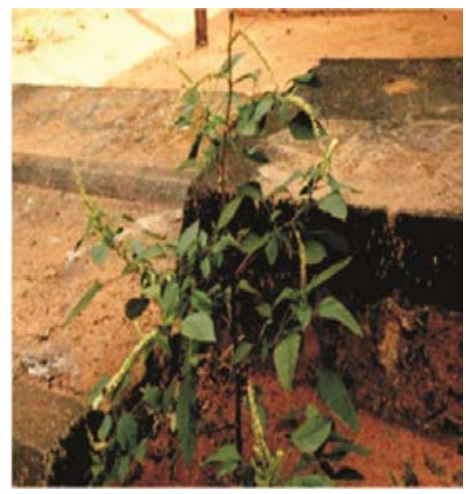

(1)

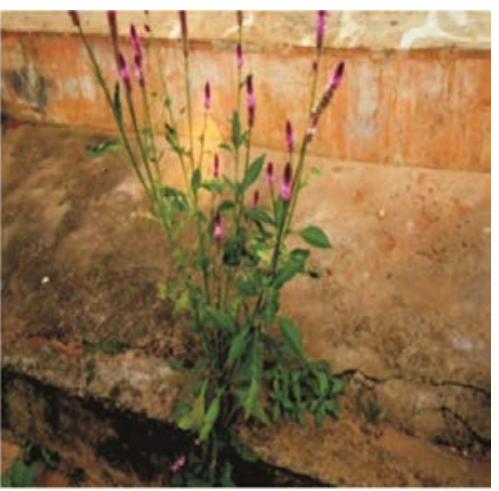

(2)

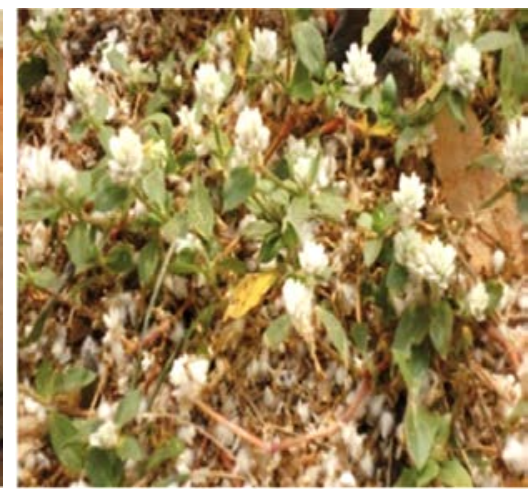

(3)

Figure 1-3. Amaranthus spinosus, Celosia argentea and Gomphrena celosioides in their natural habitat respectively

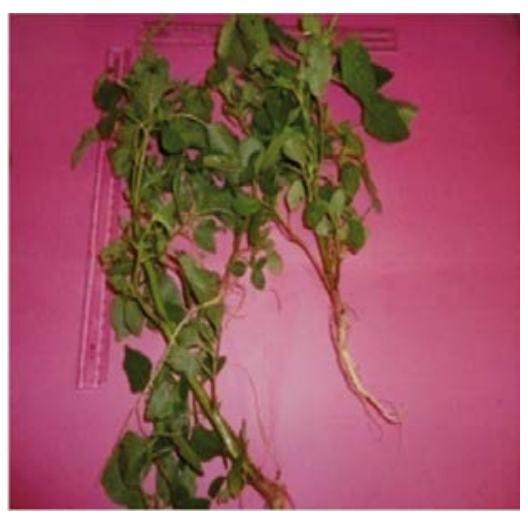

(4)

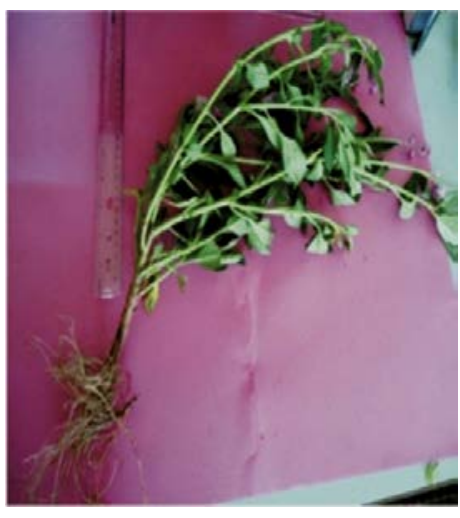

(5)

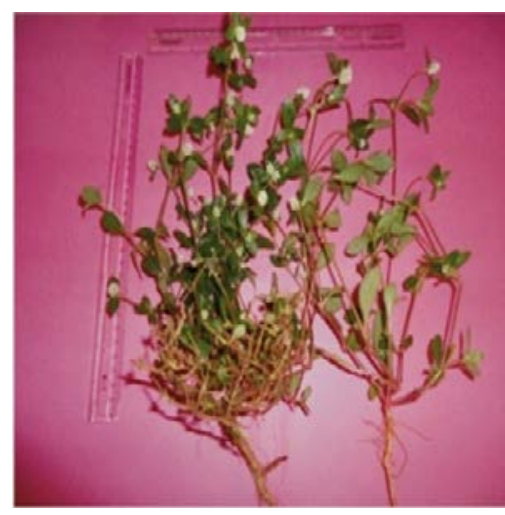

(6)

Figure 4-6. Habit morphology of A. spinosus, C. argentea and G. celosioides respectively 


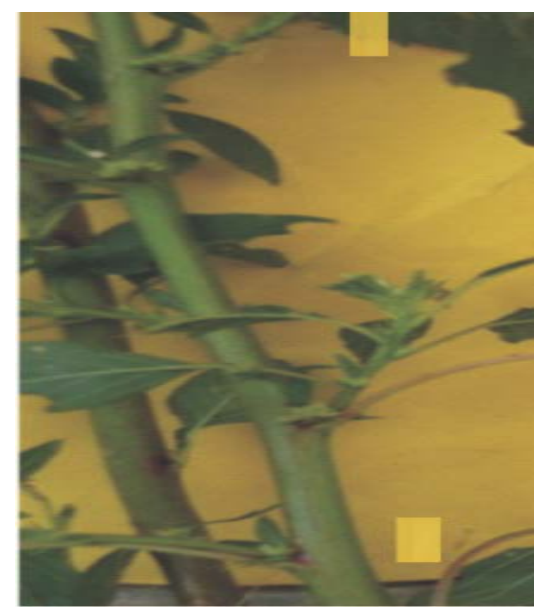

(7)

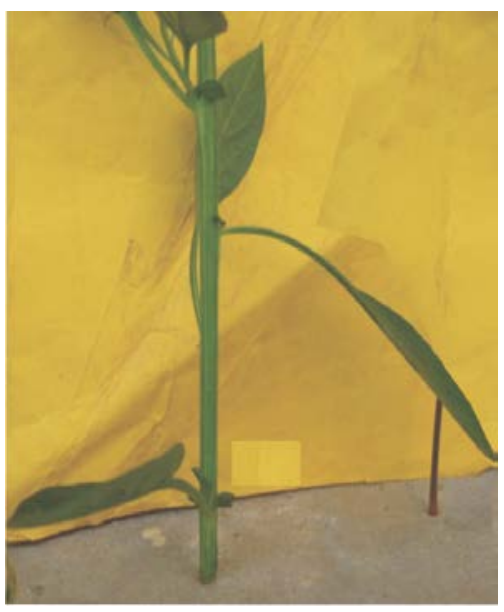

(8)

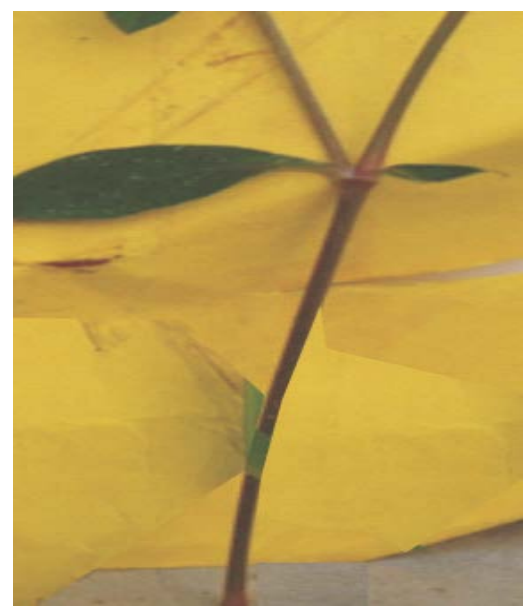

(9)

Figure 7-9. Stem morphology of A. spinosus, C. argentea and G. celosioides respectively

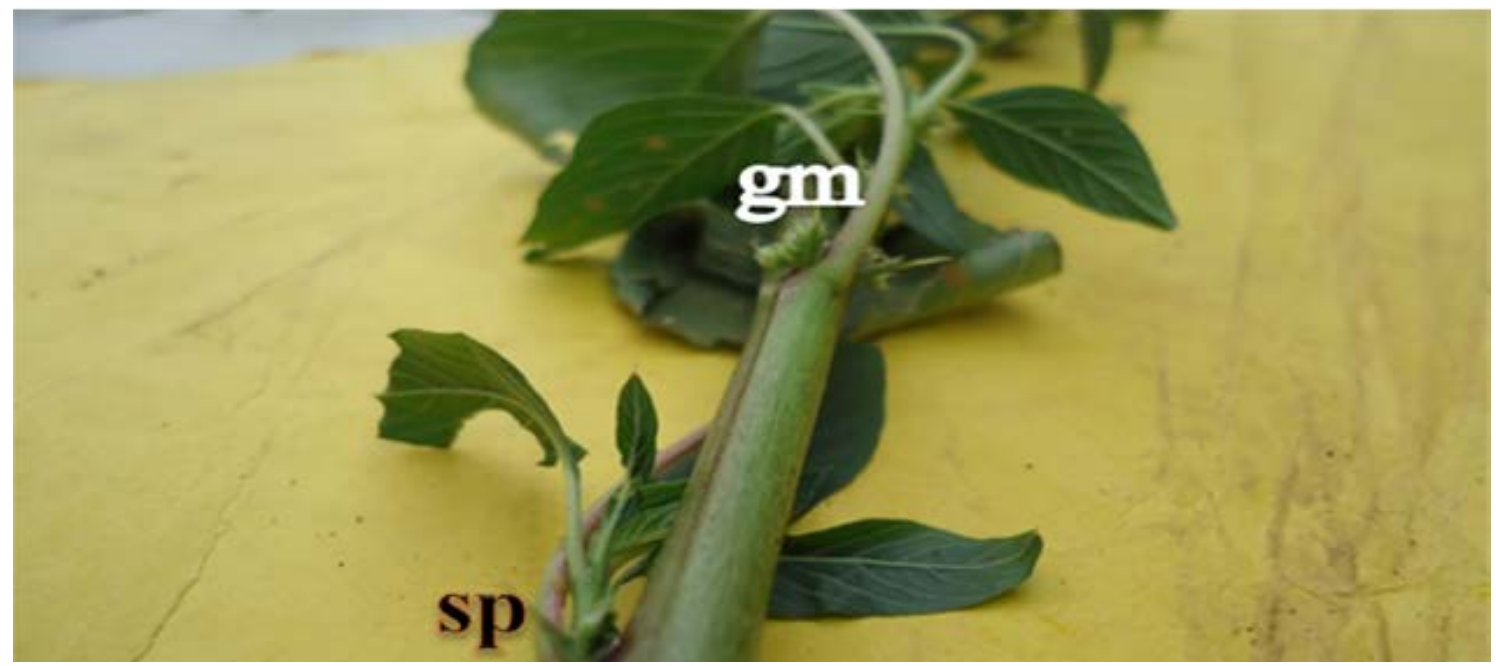

Figure 10. Amaranthus spinosus showing the spines and the glomerule around the spines (gm-glomerules, sp-spine) 


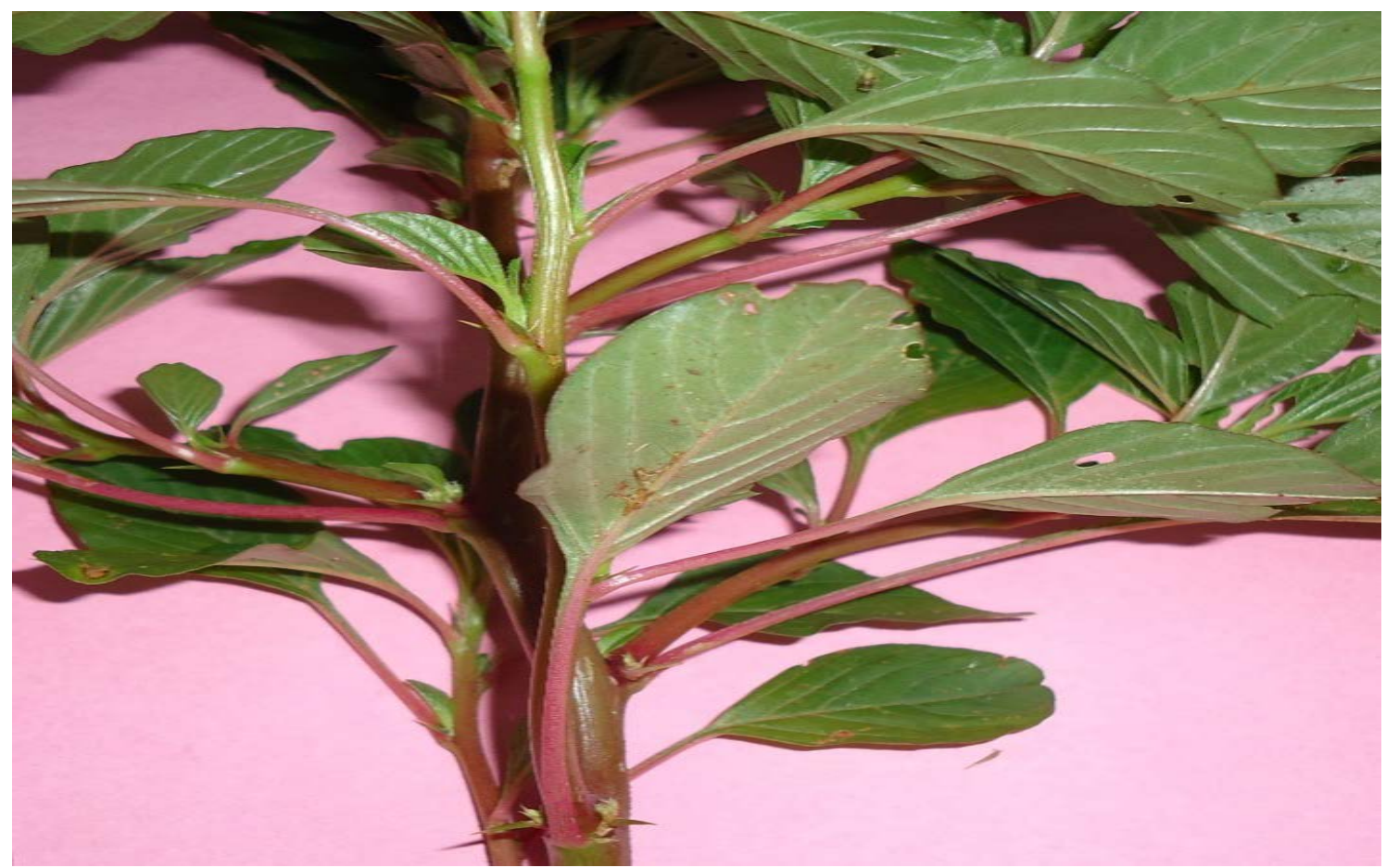

Figure 11. Stem and petiole of Amaranthus spinosus showing pink colour

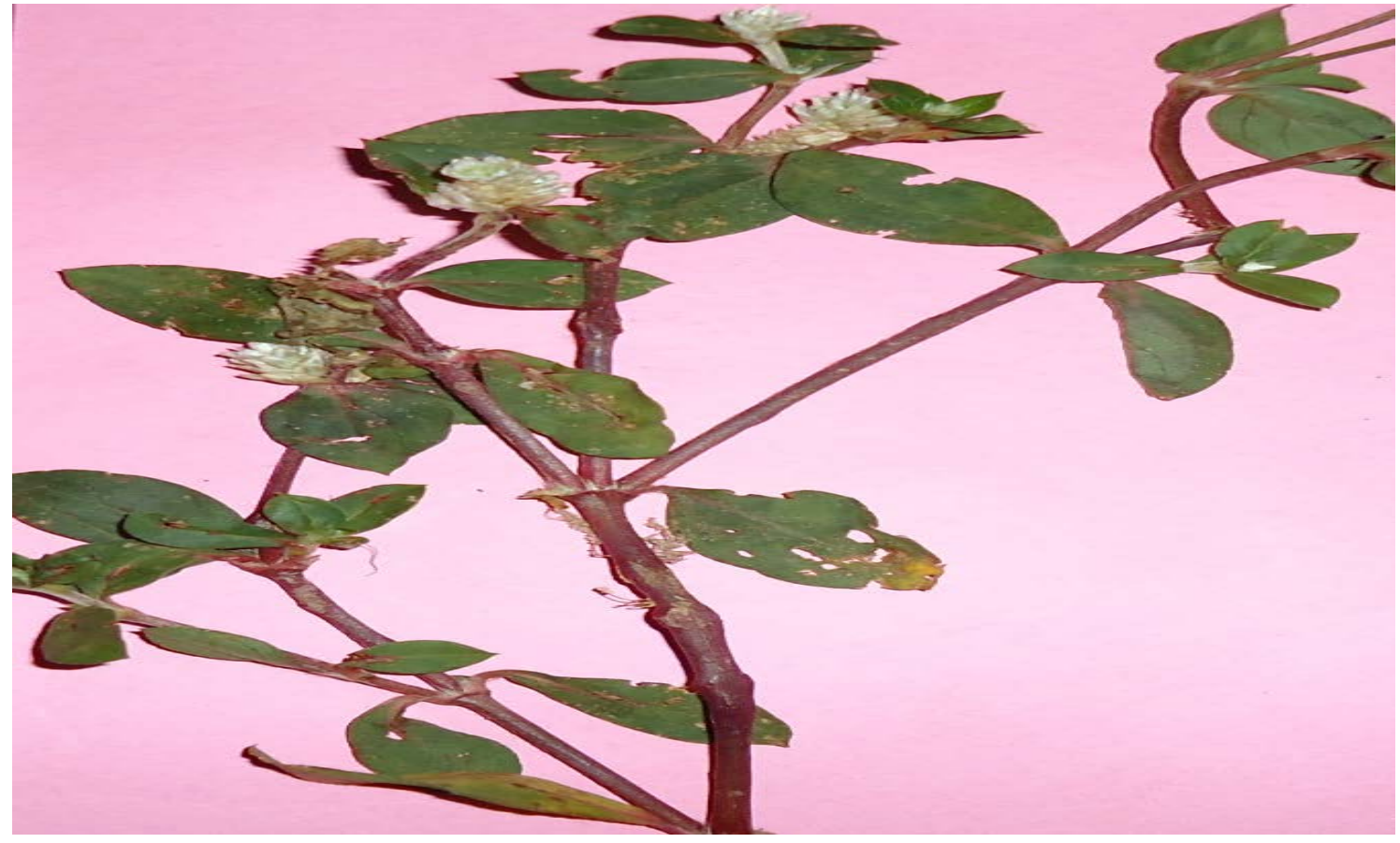

Figure12. Gomphrena celosioides stem showing pink colour

(13)

(14)

(15)

Figure 13-15. Leaf morphology of A. spinosus, C. argentea and G. celosioides respectively 


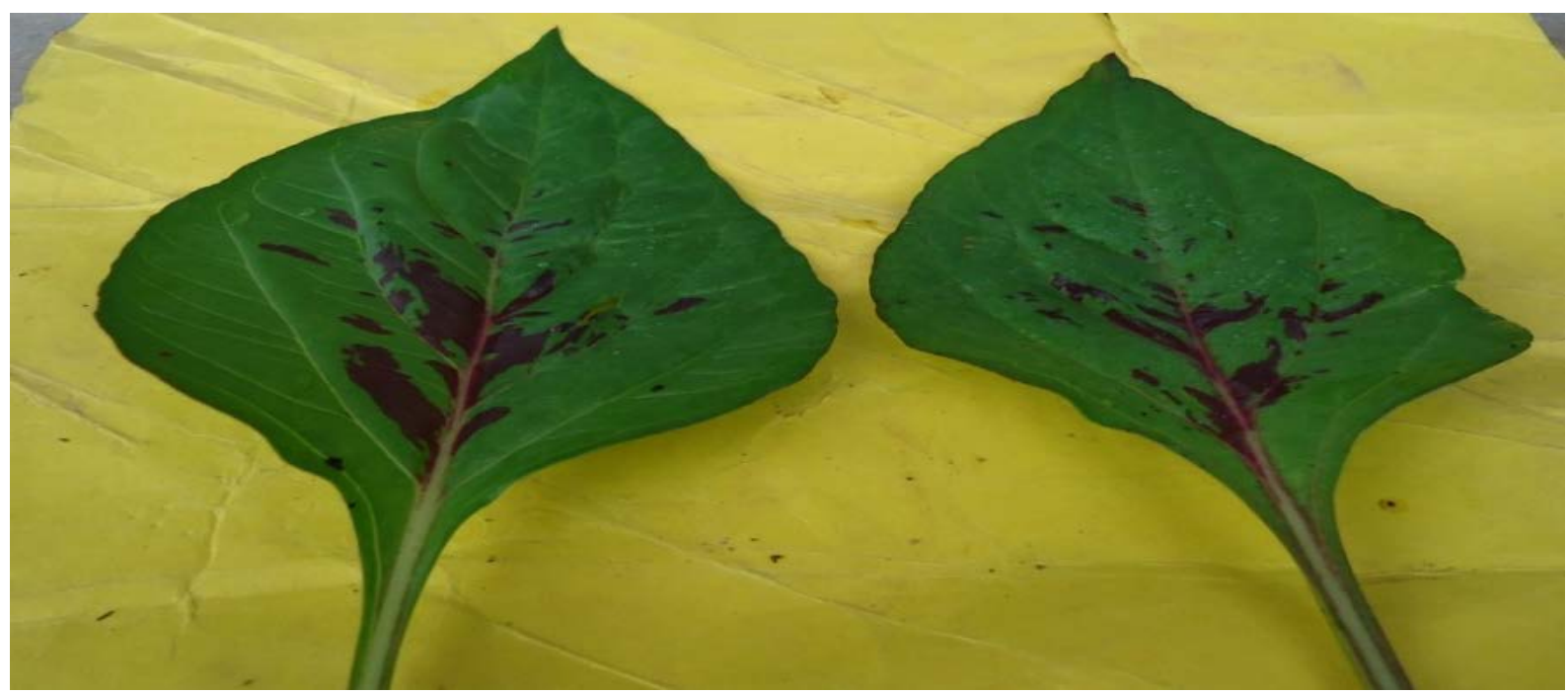

Figure 16. Celosia argentea leaves showing red patches when young

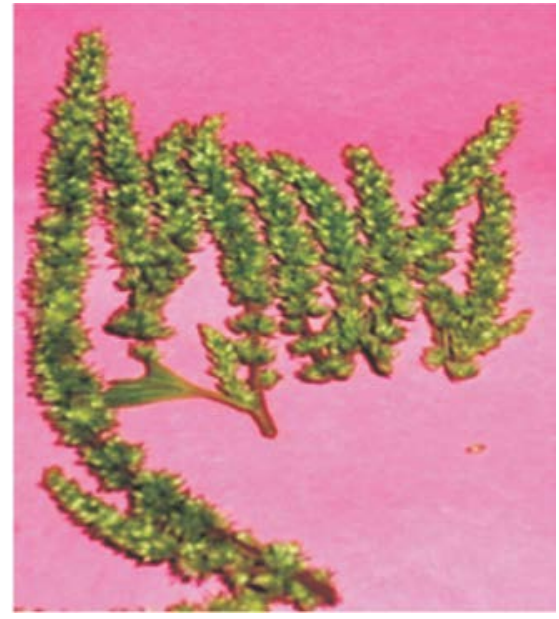

(17)

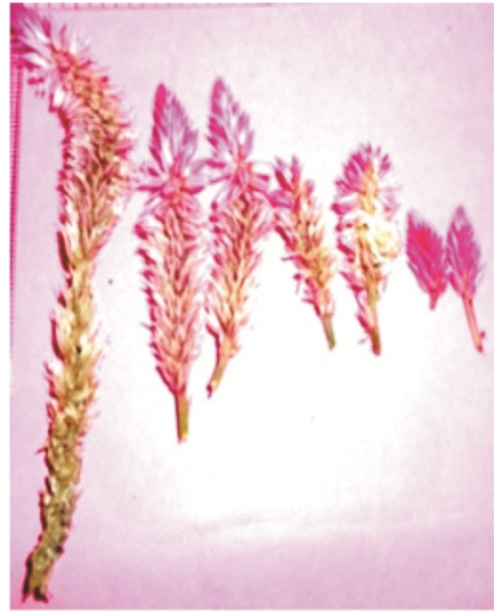

(18)

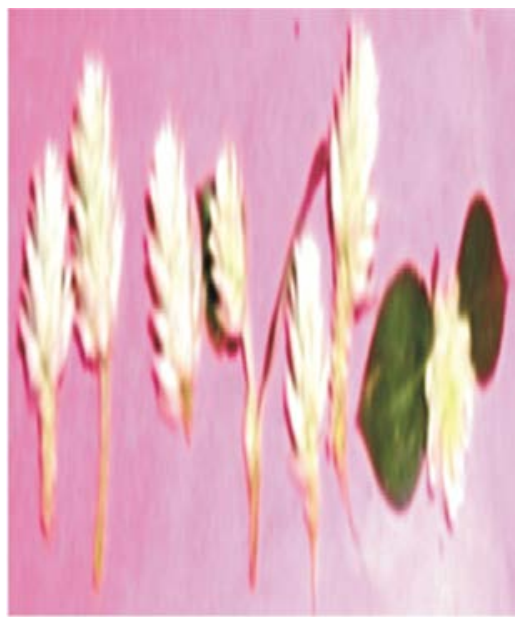

(19)

Figure 17-19. Fresh inflorescence of A. spinosus, C. argentea and G. celosioides respectively

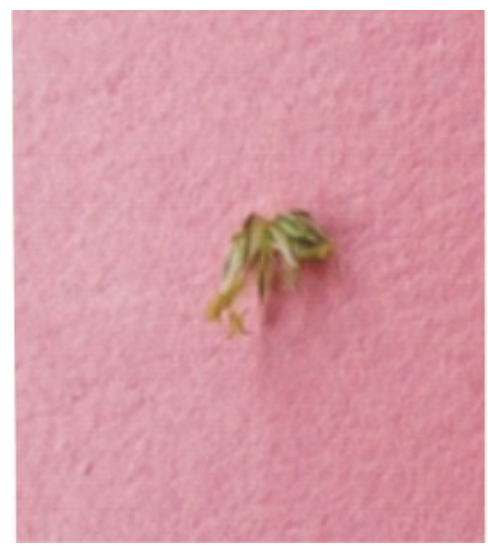

(20)

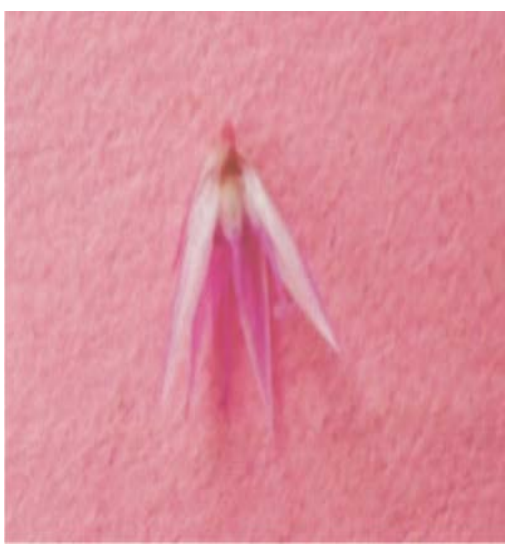

(21)

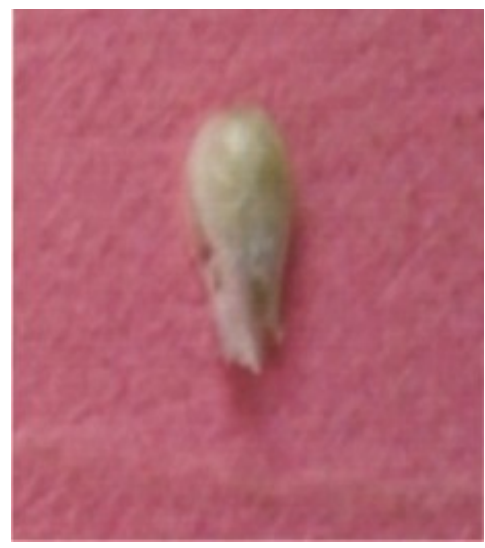

(22)

Figure 20-22. Flowers of A. spinosus, C. argentea and G. celosioides respectively 


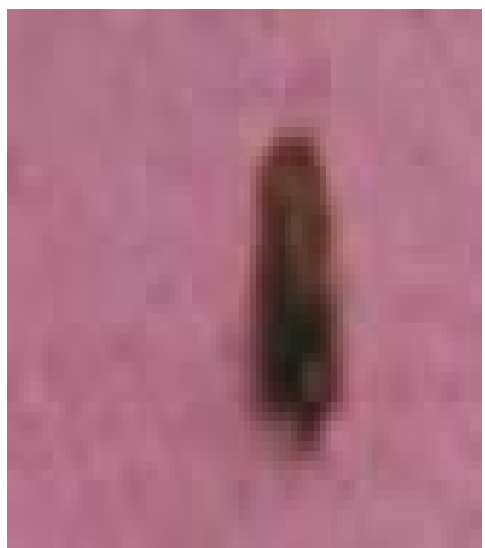

(23)

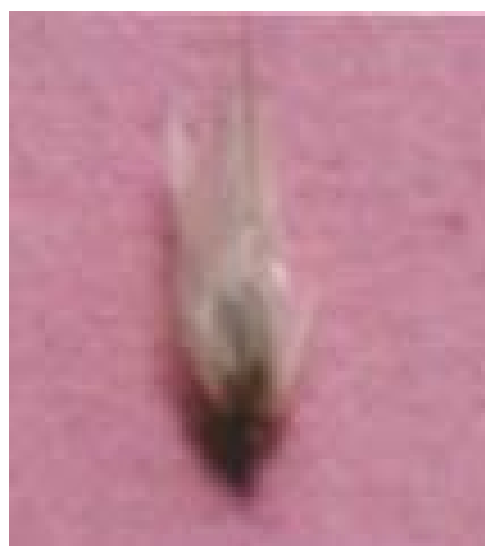

(24)

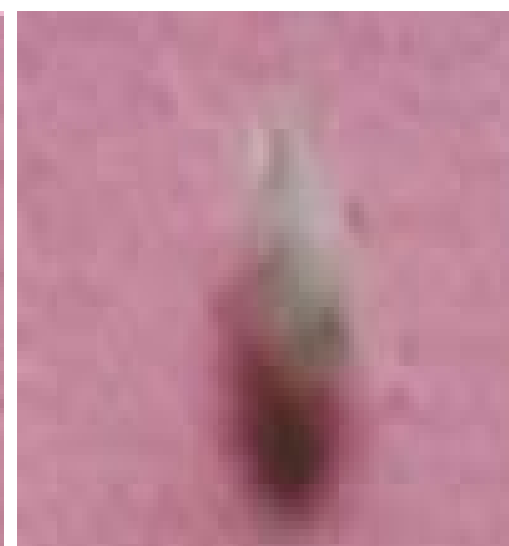

(25)

Figure 23-25. Fruits of $A$. spinosus, C. argentea and G. celosioides respectively

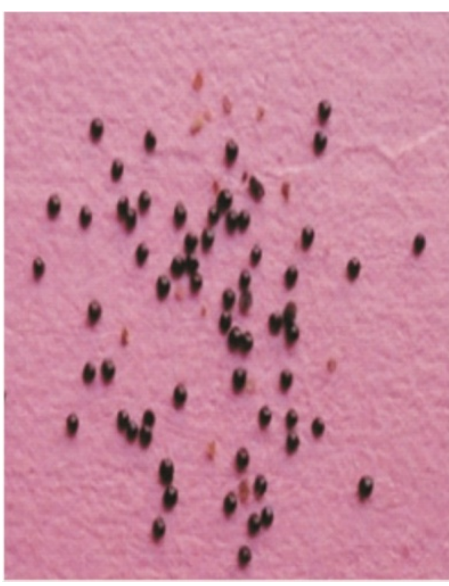

(26)

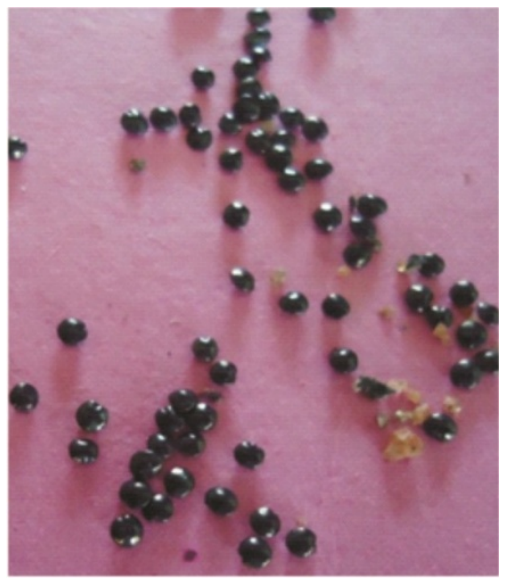

(27)

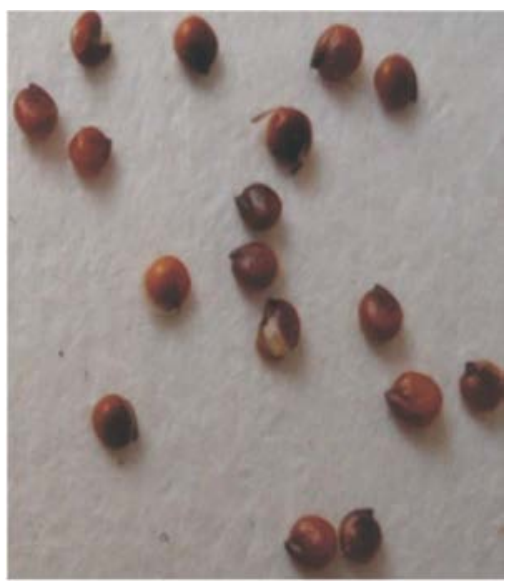

(28)

Figure 26-28. Seeds of $A$. spinosus, C. argentea and G. celosioides respectively

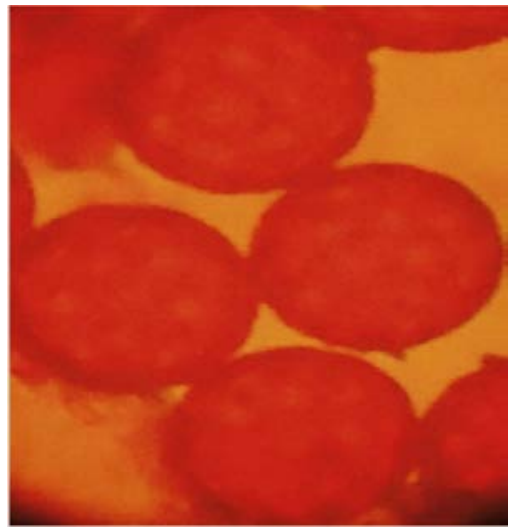

(29)

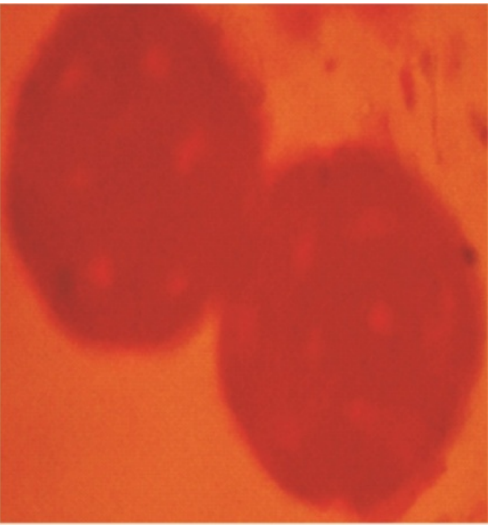

(30)

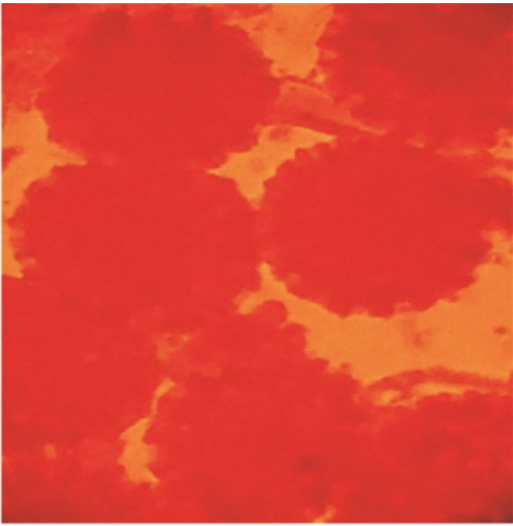

(31)

Figure 29-31. Pollen grains of A. spinosus, C. argentea and G. celosioides respectively 


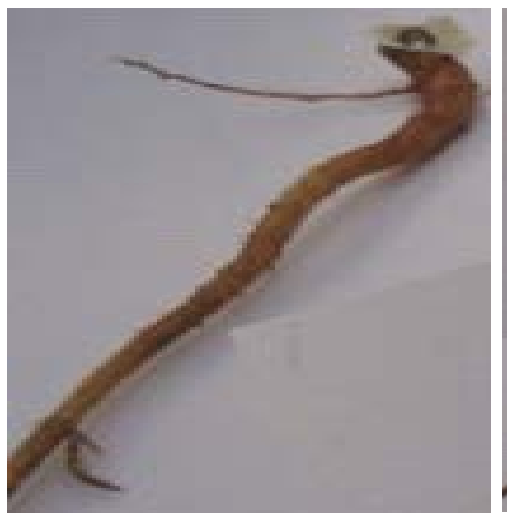

(32)

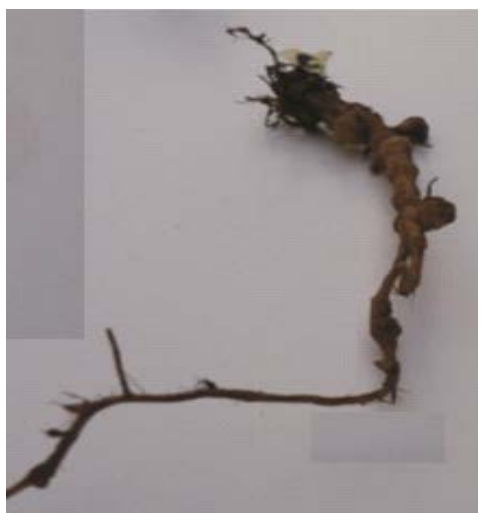

(33)

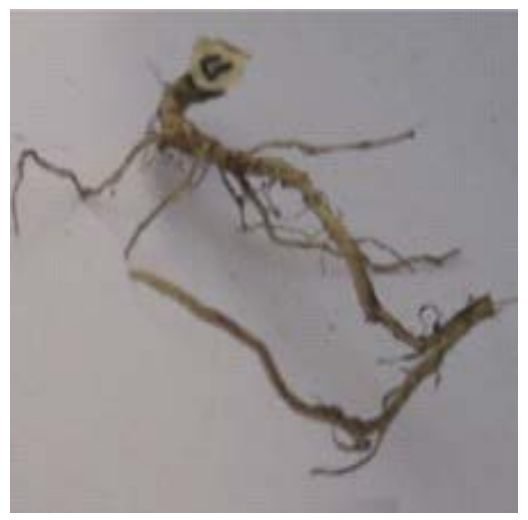

(34)

Figure 32-34. Roots of A. spinosus, C. argentea and G. celosioides respectively

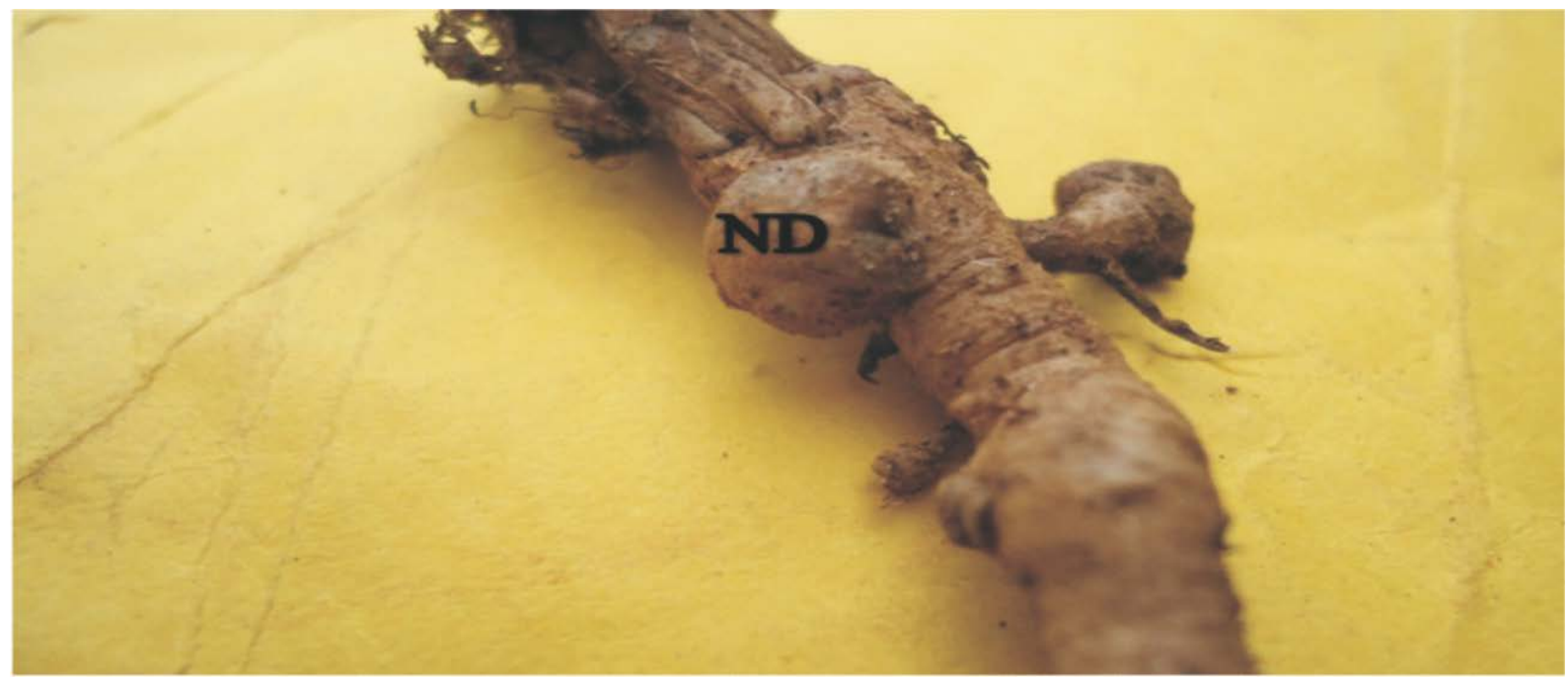

Figure 35. Root of Celosia argentea showing some nodule-like structures (ND nodule)

\section{Discussion}

The result revealed some similarities and differences in the morphological characteristics of the species (Table1, Figs 1- 35). Similarities were observed in the root type (having a taproot with many lateral roots as dicotyledonous plants), possession of simple leaves, lack of stipule, inflorescence being spikes and terminally arranged, being herbaceous with woody base, flowers being small and presence of pinkish pigment in any of the plant parts. These similarities could be because they belong to the same family Amaranthaceae. However, differences were observed in the habit (Gomphrena celosioides being prostrate and compressed at the nodes while Amaranthus spinosus and Celosia argentea were erect), plant height, leaf arrangement, leaf shape, leaf length, width, flower colour, leaf length, width, petiole length and presence of spine and hair. The differences could be the reason for the different genus and species. Qualitative and quantitative characteristics observed strengthens the interspecific relationship and can be used to enhance proper taxonomic characterization and identification of the plant species which have immense economic potentials as ornamental plants. High variability among crop genotypes based on phenotypic characters has been reported by some authors [15-20]. This is same as the report of Dutta [21] stating that the leaves of members of Amaranthaceae family are simple, opposite or alternate, entire and exstipulate. Gomphrena celosioides also possesses trichomes (hairs and papillae) which according to Cutler [22] their occurrence and cellular structure are used extensively by taxonomists as an aid to identification, since there is such a wide range of form. When a plant possesses hairs or papillae, they are usually of a type or types characteristics of that species. Gomphrena celosioides possession of trichomes, a feature that has been implicated in xeromorphy [23] helps it to withstand drought and thrives all the year round.

\section{Conclusions}

A comparative morphological study carried out on Amaranthus spinosus, Celosia argentea and Gomphrena celosioides has indeed provided some information that are useful in their delimitation as members of the family, 
Amarantheceae and also their habit and habitat. This is seen in the possession of hairs or trichomes by Gomphrena celosioides which has been a feature implicated in xeromorphy and thus helps it to thrive all the year round and with that Gomphrena celosioides can be used as ornamental. Their possession of pinkish pigment in any of the parts shows that they can be a source of vitamin a since lycopene responsible for that pinkish character has the same structure as carotene. Also to enhance proper taxonomic characterization and identification of these plant species as members of the same family.

\section{Competing Interests}

Authors have declared that no competing interests exist.

\section{REFERENCES}

[1] Gills, L.S. (1988). Taxonomy of Flowering Plants. Africana-Fep Publishers Limited. 338pp.

[2] Olutola Dosumu, O., Onocha, P, Ekundayo, O and Ali, M. (2014). "Isolation of aurantiamides from Gomphrena celosioides C. Mart". Iran Journal of Pharmaceutical Research. 13: 143-7.

[3] Akobundu, I.O. and Agyakwa, C.W. (1987). A Hand Book of West African Weeds. International Institute for Tropical Agriculture.521pp.

[4] Bown, D (1995). Encyclopaedia of Herbs and their Uses. Dorling Kindersley, London.0- 7513-020-31

[5] Duke, J.A and Ayensu, E.S. (1985). Medicinal Plants of China .0-917256-20-4

[6] Schippers, R.R. (2000). African Indigenous Vegetables: An Overview of the Cultivated Species.National Resource Institute/ ACPEU Technical Center for Agricultural and Rural Co-operation, Chattam, United Kingdom 214pp.

[7] Yeung, H. (1985). Hand book of Chinese Herbs and Formulas. Institute of Chinese Medicine, LOS Angeles.

[8] Kirtikar, K and Basu, L. (1935). Indian Medicinal Plants. 2nd ed, Allahabad.111:2053- 2054.

[9] Onocha, P.A., Ajaiyeoba, E.O., Dosumu, O.O and Ekundayo, O. (2005). Phytochemical screening and biological activities of Gomphrena celosioides Mart extracts. Nigerian Society Experiment.; 5: 59-65.

[10] Burkill, H.M. (1984). The Useful Plants of West Tropical Africa. Royal Botanical Gardens Kew;

[11] Ilodibia, C. V., Okeke, C.U., Chukwuma, M. U., Okeke, N. F., Akachukwu, E. E and Aziagba, B. O. (2015). Taxonomic Significance of Morphology and Palynology of two Species of Dracaena found Southeastern Nigeria, International Journal of Biological Research 3 (1): 5-8

[12] Radford, A.E.(1986).Fundamentals of Plant Systematic,
Harper and Row, New York. Pp.302-322.

[13] Sharma, O. P. (1993). Plant Taxonomy (1st Ed.) Tatam Mc Graw-Hill Publishing Company Limited, New Delhi. 482pp.

[14] Ilodibia, C.V., Nnaji, E., Aziagba, B.O. and Ezeabara, C.A. (2017). Morphological and Nutritional Assessment of leaf, stem and root of Zanthoxylum macrophylla (Rutaceae). Archives of Agriculture and Environmental Science, 2(1): 44-46.

[15] Aremu, C. O., Ariyo, O.J. and Adewale, B. D. (2007). Assessment of Selection Techniques in Genotype $\mathrm{X}$ Environment Interaction in Cowpea Vigna unguiculata (.L.) Walp. African Journal of Agricultural Resource, 2: 352-355.

[16] Adewale, B.D., Okonji, C., Oyekanmi, A. A., Akintobi, D.A.C. and Aremu, C.O. (2010). Genotypic Variability and Stability of Some Grain Yield Components of Cowpea. African Journal of Agricultural Resource, 5; 874-880.

[17] Aziagba, B. O., Okeke, C. U., Ezeabara, C. A., Ilodibia, C. V., and Obika, I. E. (2016).Taxonomic Implication of Morphology of Seven Varieties of Vigna unguiculata (L.) Walp. Cultivated in Awka, Anambra State, South Eastern Nigeria. America Journal of Life Science Researches 4(4): 132-137

[18] Ilodibia, C. V., Arubalueze, C. U, Udeorah, S. N., Okafor, B. I. and Agbanusi, C. (2018). Assessment of Morphological and Nutritional Attributes of Two Varieties of Ipomoea Batatas L. Utilized in Nigeria. Archives of Agriculture and Environmental Science, 3(4): 394-398

[19] Ilodibia, C. V., Okoli, B. E. and Okeke, C. U. (2019). Evaluation of Cytological and Morphological Traits of Morinda lucida Benth. - An Under- exploited Tropical Species. Asian Journal Biological Sciences; 12(4): 891-897

[20] Ilodibia, C. V., Achebe, U. A., Arubalueze, C.U and Ibeh, E. (2019). A Comparative Study on Morphology, Mineral and Vitamin Compositions of two Variants of Hibiscus sabdariffa L. Archives of Agriculture and Environmental Science; 4(1): 50-56

[21] Dutta, A. C. (2009). Botany for Degree Students (Revised Edition) Oxford University Press. 708 pp.

[22] Cutler, D. F. (1978). Applied Plant Anatomy. Longman Inc., New York. 99pp.

[23] Esau, K. (1977).Anatomy of Seed Plants (2nd Ed.) John Wiley and sons incorporated, Canada. 550pp. 